\title{
Microfossil Assemblage from Dhok Pathan Formation (Middle Siwaliks) exposed near Polian Prohita, Una District, Himachal Pradesh, India
}

\author{
K. Milankumar Sharma ${ }^{1}$, Shyam Sundar $\operatorname{Singh}^{2}$ and Vipina P.V. ${ }^{2}$ \\ ${ }^{1}$ Palaeontology Division-1, Central Headquarters, \\ Geological Survey of India, 15 Kyd Street, Kolkata-700016 \\ ${ }^{2}$ Geological Survey of India, Chandigarh-160033 \\ Email: milankumar.sharma@gmail.com
}

\begin{abstract}
The Fluvial molassic sediments of Middle Siwalik which is considered to be deposited within the time range from 10.1-5.1 Ma holds a long record of the provenance and palaeoenvironmental history of Siwalik foreland basin. A mudstone bed of Dhok Pathan Formation exposed near Polian Prohita, Una district, Himachal Pradesh has yielded a diverse fossil assemblage. The present assemblage include mollusks Parreysia sp., Lamillidens sp., Melanoides sp. and Gyraulus sp. The charophytes include Chara globularis globularis, Chara globularis aspera, Chara sp. indet, Lychnothamus breviovatus and Lamprothamnium papulosum. Ostracodes Stenocypris sp. and Candona sp. have also been reported here. Fish teeth of certain morphotypes belonging to the Channidae and Cyprinidae families were also recorded. The majority of the fossil assemblage suggested that a warm tropical to subtropical humid climatic condition was prevailing during the deposition of these sediments. As this fossil assemblage is found restricted to a particular mudstone bed it can be inferred that there existed a localized swampy to overbank pond environment in within the braided river system deposits of Dhok Pathan Formation.
\end{abstract}

Keywords: Microfossils, Charophytes, Dhok Pathan Formation, Palaeoenvironment.

\section{Introduction}

The Siwalik Group is a freshwater molassic deposit of more than $\sim 6000 \mathrm{~m}$ thickness, deposited in the foredeep basin known as Himalayan Foreland Basin (HFB) formed during the rise of the Himalayas, and preserves a long record ( 18 to $0.5 \mathrm{Ma}$ ) of alluvial sedimentation associated with vertebrates, invertebrates and plant fossils (see, Sangode et al., 2001; Nanda, 1997; Bhatia and Mathur, 1978; Lakhanpal and Guleria, 1987). The fluvial deposits of the Middle Siwalik sediments show vertical facies variation having an overall coarsening upward sequence of predominant multistoried sandstone complex with subordinate overbank mudstone units reflecting a significant event related to the deformation along the Main Central Thrust commencing around 10 Ma (Burbank et al., 1996; Meigs et al., 1995; Tandon, 1991).

The Dhok Pathan Formation of Middle Siwalik Group is considered to be deposited during the time ranges of 7.9 to 5.1 Ma i.e. Late Miocene to Middle Pliocene age (Sangode et al., 2003; Johnson et al., 1982, 1983). Biostratigraphic records indicate a remarkably high biodiversity during the Siwalik era and the Plio-Pleistocene transition period also signifies a major faunal 
change related to climate. Prior to the present work, certain workers such as, Bhatia and Mathur (1971); Tewari and Sharma (1972); Lakhanpal et al. (1976); Bhatia (1982); Liu (1989); Bhatia (1996); Kundal et al. (2008) carried out palaeontological studies on Siwalik Charophytes. Bhatia and Khosla (1967) recovered ostracod remains for first time from the Tatrot Formation of the Upper Siwalik Subgroup exposed near Chandigarh in India and their work is followed by workers namely, Mathur (1975, 1998); Raghavan (1990); Bhatia (1996); Bhandari and Kundal (2008). Bhatia and Mathur (1973), Mathur (1998); Gurung (1998) described freshwater molluscs from Siwalik of India and Nepal. Cyprinid fish teeth were also described from the Karewas of Kashmir (Kotlia, 1985) and from the Upper Siwalik subgroup of Jammu and Kashmir near Khanpur village (Kundal and Prasad, 2011).

Even though many researchers have done enormous work in different fields of Siwalik geology (Ranga Rao, et al. 1988; Johnson, et al., 1985; Kumar and Nanda, 1989; Thomas et al., 2002; Kumar et al., 2004; Kumaravel et al., 2010), till date a meager amount of work has been accomplished in palaeoclimatic and palaeoecological reconstructions (also see, Patnaik, 2003; Thomas et al., 2002; Johnson, 1977; Retallack, 1995; Sanyal, et al. 2004; Kumaravel, et al. 2005, 2009). The present paper describes some of the identifiable fossil remains of charophytes, ostracods, mollusc and fish teeth from this area and discussed their palaeoenvironmental significance.

\section{Geology and Stratigraphy}

Pilgrim (1910, 1913), on the basis of faunal recovery, divided the Siwalik succession into three units namely the Lower, Middle and Upper Siwalik Series which are again further divisible as Kamlial and Chinji stages for the Lower Siwalik Series; Nagri and Dhok Pathan stages for Middle Siwalik Series and the Upper Siwalik series into Tatrot, Pinjore and Boulder Conglomerate stages (Pilgrim, 1934). The type sections of Kamlial, Chinji, Nagri, Dhok Pathan, and Tatrot Formations of Siwalik Group occur in Pakistan and Pinjore, Boulder Conglomerate formations occur in India. However, certain reference sections with similar fossils are also known to occur in India, Pakistan and Nepal.

The Middle Siwalik fluvial sediments of Nagri and Dhok Pathan formations is characterized by thick multistoried sandstone complex associated with subordinate overbank mudstone units (Kumaravel et al., 2005). Within the Dhok Pathan Formation (Middle Siwalik) exposed around Polian Prohita (Figs. 1a,b) as many as 31 numbers of cyclic sedimentation are recorded (Fig. 1c). Each cycle starts with pebbly to gritty coarse greyish sandstone and ends with very fine sand, silt or mudstone. At two locations cycles starting with conglomerate units are also recorded. The percentage ratio of gravel: sand: silt or clay is 2.4\%: 90.7\%: 6.9\%. Occurrence of granule, cobbles and pebbles as well as primary sedimentary structures like trough cross lamination and horizontal lamination, ripple marks and convolute lamination have also been observed at number of places. A number of erosional surfaces are observed within the thick massive sandstone with calcretisation of Dhok Pathan Formation. This indicates the multi-storied nature of the sandstone units, each deposited by the infilling of a river channel, stacked one above the other with little or no intervening mudstone. The mudstone units intercalated within the sandstone are of variegated nature and narrow in thickness. 
Open access e-Journal

Earth Science India, eISSN: 0974 - 8350

Vol. 8 (I), January, 2015, pp. 15-31

http://www.earthscienceindia.info/

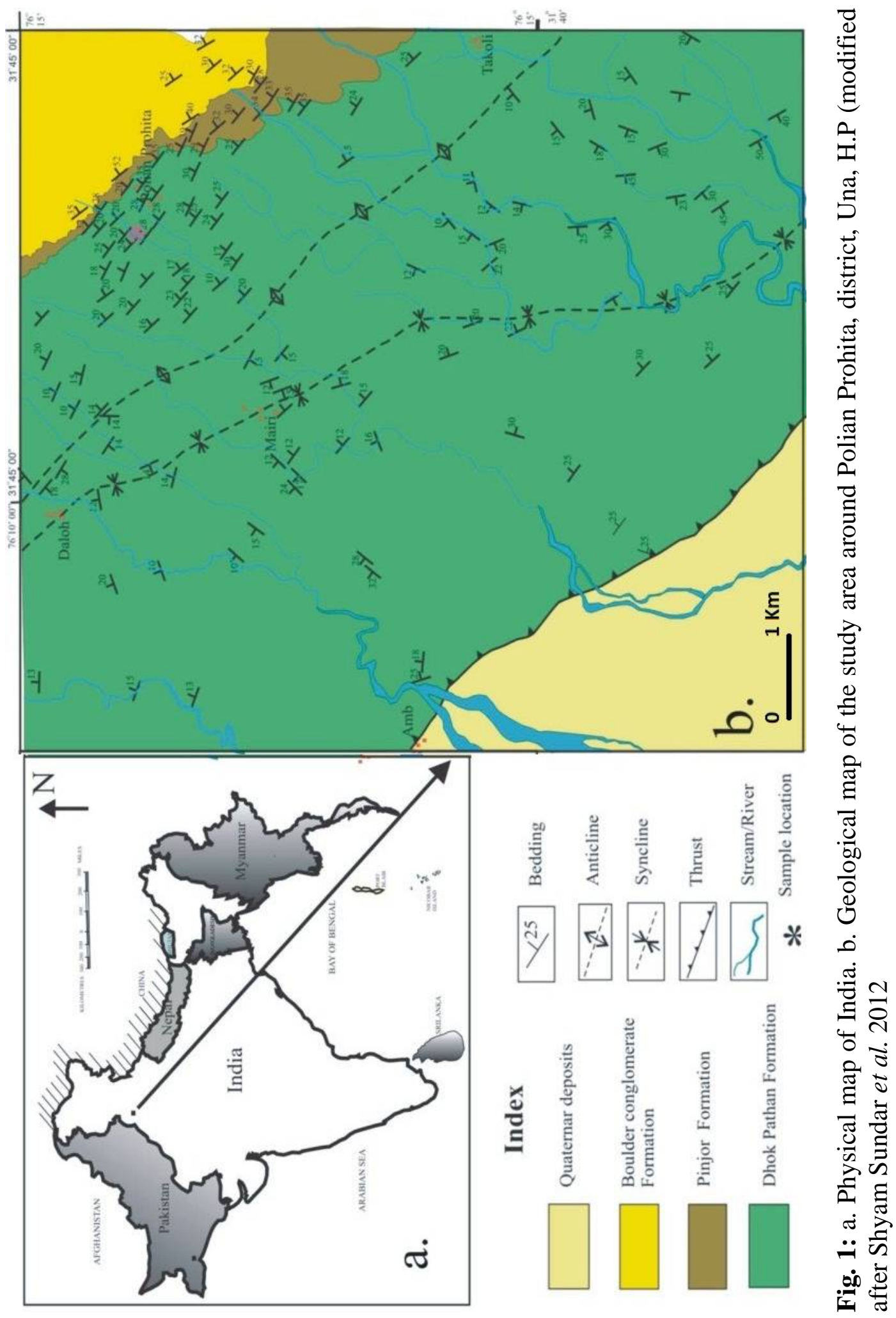



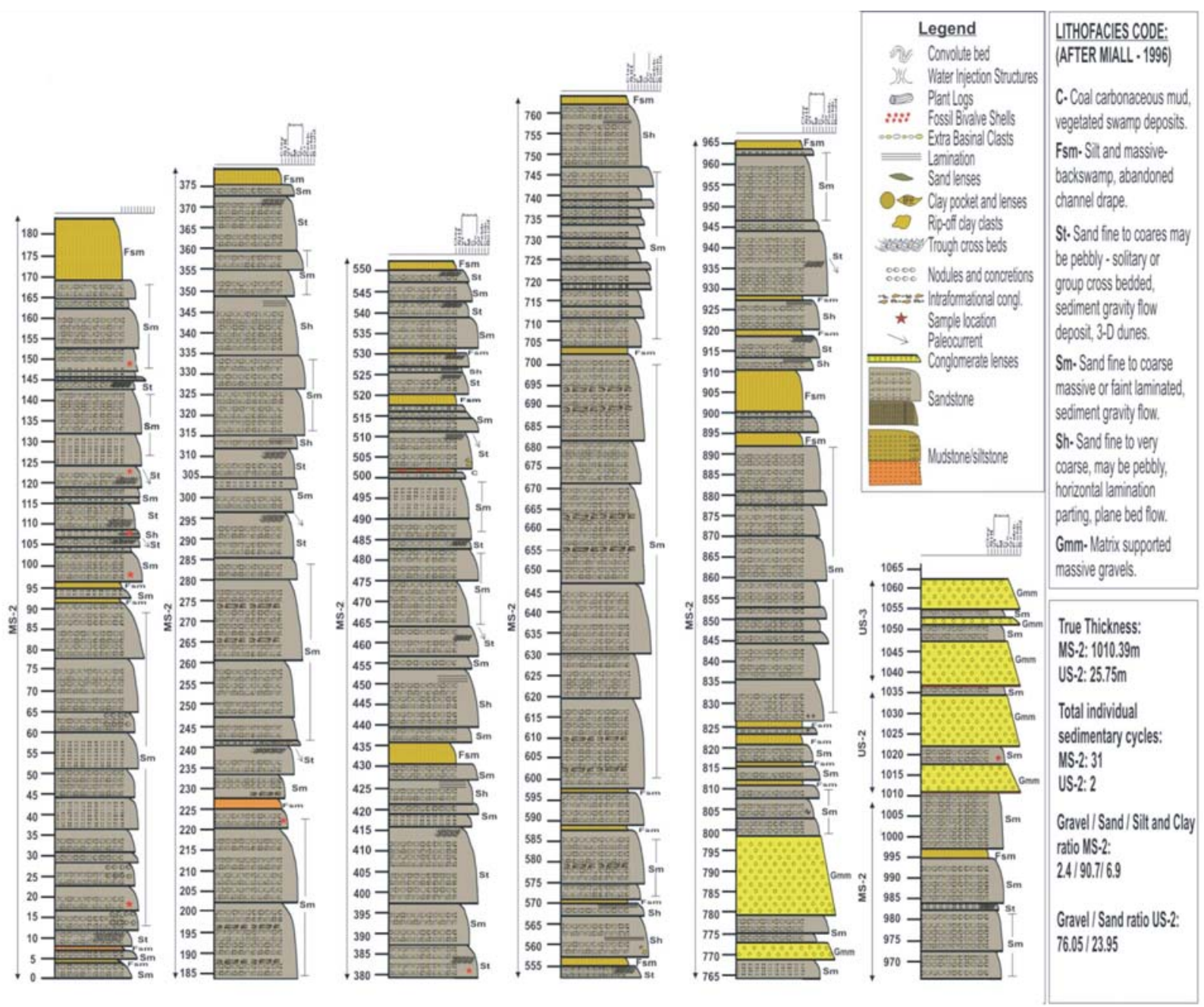

Fig. 2: Litholog of Dhok Pathan Formation exposed around Polian Prohita-Bharowar area (source, Shyam Sundar et al., 2012).

During the field work carried out in District Una, Himachal Pradesh for the execution of the Geological Survey of India Field Season Programme item no. STM/NR/PHH/2010/005, a mudstone band associated with rich fossil assemblage has been recorded from Polian Prohita village near Kamikhya Temple (Fig. 1\& 2; Plate-1: fig. A). This bed belongs to the Dhok Pathan Formation of Middle Siwalik Subgroup. The mudstone bed is intercalated with gritty to coarse grained soft greenish to grayish colour multistoried sandstones and siltstone. However, only a particular horizon of mudstone is fossiliferous. A number of poorly preserved fossilized mollusk shells were collected from this bed. Maceration of the micropalaeontological samples collected from this bed yields a large number of microfossil such as Charophytes, Ostracodes and certain fossil fish teeth.

\section{Methodology}

The samples collected from Polian Prohita area ( 20 kgs) were macerated with water, water and acetic acid and water and kerosene depending on the hardness of the samples. The disintegrated and loose macerates of the above samples were subjected to wet sieving process in 
Open access e-Journal

Earth Science India, eISSN: $0974-8350$

Vol. 8 (I), January, 2015, pp. 15-31

http://www.earthscienceindia.info/

which the macerates were passed through sieves ranging from 40-80 mesh. The residues collected from the sieves were made dry at first and then were seen under the binocular microscope for picking the fossils. The collected microfossils were studied under the Leica S8 APO stereo zoom binocular microscope housed at the Department of Geology, Panjab University, Chandigarh. The collected specimens carrying specimen numbers $\mathrm{Si} / \mathrm{pal} / 001$ to $\mathrm{Si} /$ pal/028 were stored at GSI, Chandigarh.

\author{
Systematic Palaeontology \\ Class: Bivalvia \\ Subclass: Palaeoheterodonta \\ Order: Unionoida \\ Superfamily: Uninacea \\ Family: Uninoidae \\ Subfamily: Uninae \\ Genus: Parreysia Conrad, 1853 \\ Parreysia sp. \\ (Plate 1: fig. 1)
}

Material and horizon: - Si/pal/001 and several poorly preserved specimens from dark grey to blackish mudstone bed of Dhok Pathan Formation near Kamikhya Temple, Polian Prohita area.

Remarks: - Medium size, shell convex, subcircular outline, umbo is anterior to the middle, inflated with zig-zag ridges, umbonal sculpture extending to the middle of the shell, dorsal margin slightly arched, anterior and posterior margins are broadly rounded, anteriodorsal angulation is obtuse, posteriodorsal angulation smoothly arched, growth lines are prominent and moderately widely spaced; ventral margin is semicircular, umbo bears corrugations. Inner details are lacking. The genus Parreysia is a long ranging bivalve mostly found in the Chinji, Dhok Pathan, Tatrot and Pinjore formations of Siwalik (Mathur, 1998; Mathur, 1975; Vokes 1935). The present specimen resembles the Parreysia sp. indet. of Mathur (1998). Precise specific identification of the specimen is not possible due to poor nature of preservation.

\title{
Genus: Lamellidens Simpson, 1900 \\ Lamellidens sp. indet.
}

(Plate. 1; fig. 2)

Material and horizon: - One partially broken specimen (Si/pal/002) and three poorly preserved specimens from dark grey to blackish mudstone bed of Dhok Pathan Formation near Kamikhya Temple, Polian Prohita area.

Comments: - Specimen partially broken, large, broadly elliptical to subtrapazoidal, moderately compressed, unequilateral and highly inflated; the beak are prominent and placed anteriorly. The incompleteness of the specimen makes it difficult to assign it to a particular species. The genus Lamellidens has also been described from the Lower, Upper and Middle Siwaliks (Mathur, 1998; Mathur, 1975; Bhatia \& Mathur, 1973; Vokes, 1935; Prasad, 1927). This long ranging genus is particularly found restricted in the geological range of Chinji to Pinjor. 


\section{Class: Gastropoda \\ Subclass: Pulmonata \\ Order: Basommatophora \\ Family: Planorbidae \\ Subfamily: Planorbinae \\ Genus: Gyraulus Agassiz 1837, in Carpentier 1837 \\ Gyraurus sp. indet}

(Plate 1; fig. 3)

Material and horizon: - Single specimen Si/pal/004 collected and several poorly preserved specimens from dark grey to blackish mudstone bed of Dhok Pathan Formation near Kamikhya Temple, Polian Prohita area.

Comments: - Specimen is small in size, discoidal, planispirally coiled, whorls two and half, convex, size increasing rapidly with growth, all the whorls are visible from above. The incomplete preservation of the specimen makes it difficult to identify up to the species level. The present specimen resembles to Gyraulus sp. of Bhatia and Mathur (1971) in which they showed a close resemblance of their specimen with $G$. singularis Mousson. The present specimen is also comparable with those of Gyraulus reported by Bhatia (1969) from the Karewa deposits of Kashmir.

\title{
Order: Mesogastropoda \\ Family: Thiaridae \\ Genus: Melanoides Oliver, 1807 \\ Melanoides sp. indet
}

(Plate 1; fig. 4)

Material and horizon: - Si/pal/004 and two unnumbered poorly preserved specimens from dark grey to blackish mudstone bed of Dhok Pathan Formation near Kamikhya Temple, Polian Prohita area.

Comments: - Shell small, poorly preserved, elongated; apex slightly pointed. Total number of whorls may be variable from 5 to 7; whorls are spiral, ornamented with tubules and sculpture with stripes, body whorl is large and inflated. The apex shows an acute angle. The aperture portion of the specimen is not well preserved.

Remarks: - The present specimen is similar with the Melanoides tuberculata of Bhatia and Mathur (1973) which has been reported from the Pinjore Formation. Mathur (1998) also described Melanoides tuberculata from the Dhok Pathan Formation (Middle Siwalik) of Daulatpur area. This particular species has an extensive geographical distribution. It has also been reported from Pliocene- Pliestocene deposits of the Oriental, Ethiopia and Palaeartic regions (Benthem Jutting, 1950; Brown, 1965; Mathur, 1998). However, it is difficult to assign the present specimen to a particular species due to poor preservation.

\author{
Order: - Charales \\ Family: - Characeae \\ Subfamily: - Charoideae \\ Genus: - Chara Linne, 1753 \\ Chara globularis globularis Thuillier
}

(Plate 1: fig. 5) 
Materials and Horizon: Si/pal/005 from dark grey to blackish mudstone bed of Dhok Pathan Formation near Kamikhya Temple, Polian Prohita area.

Comments: Gyrogonites are medium size, prolate spheroidal to subprolate; apical portion broadly rounded and the basal portion broadly subtruncated; apical periphery truncated at the lateral view; nine to thirteen, thick, convex and wide convolution which are thinner at the apical periphery, peripheral groove is visible, moderately high five apical cells forms an apical rosette, apical cell meet at a zig-zag line; basal pore is pentagonal to circular and basal plug is as thick as wide.

Remarks: Bhatia and Mathur (1978) described Chara globularis globularis as Chara surajpurica. It is synonymous to Chara indica of Tewari and Sharma (1972). Bhatia (1999) revised the species as Chara globularis globularis. This extant cosmopolitan species is frequent to abundant in the Dhok Pathan, Tatrot and Pinjor Formation.

\section{Chara globularis aspera (Deth. ex Wild.) Wood}

(Plate 1: fig. 6)

Materials and Horizon: -- Si/pal/006 from dark grey to blackish mudstone bed of Dhok Pathan Formation near Kamikhya Temple, Polian Prohita area.

Comments: - Gyrogonites is small, prolate to ellipsoidal in shape, apical portion slightly protruding and subrounded, apex concave with five opercular cells which joined nearly at a point or along a short straight line; ten to twelve flat to concave, moderately thick convolution without any ornamentation, basal pore is pentagonal to subcircular without any depression.

Remarks: - Proctor (1980) considered this subspecies to be the dioecious representative of monocoius Chara globularis. Bhatia and Mathur (1978) recorded Chara contraria from the Pinjore Formation near Chandigarh and later Bhatia (1999) revised it with additional fossil records from the Tatrot Formation near Dhamala village and Pinjor Formation of Nada village and Choti Parch village. The species has also been described from the Quaternary marls of IndoGangetic plain Bhatia and Singh (1989). The present finding extends the geological range of the species upto Dhok Pathan Formation.

\section{Chara sp. indet}

(Plate 2: fig. 1)

Materials and Horizon: -- Single specimen Si/pal/007 from dark grey to blackish mudstone bed of Dhok Pathan Formation near Kamikhya Temple, Polian Prohita area.

Comments: - Gyrogonites are small to medium, subovoidal to sub-globular, apical rounded to sub-truncate, eight to twelve, moderately thick and wide convolutions without ornamentation, narrowed in the apical periphery, intercellular ridge are prominent, apical cells form a not-sowell developed rosette, basal pore is pentagonal to sub-circular without outer basal depression. Basal plug is thick as wide.

Remarks: - The present specimen is similar with the Chara rantzieni of Tewari and Sharma (1972), Bhatia and Mathur (1978) which described from the Tatrot formation near Naipli village and near Chandigarh respectively. However, lack of well developed apical rosette in the present specimen makes it difficult to assign the specimen to Chara rantzieni. 


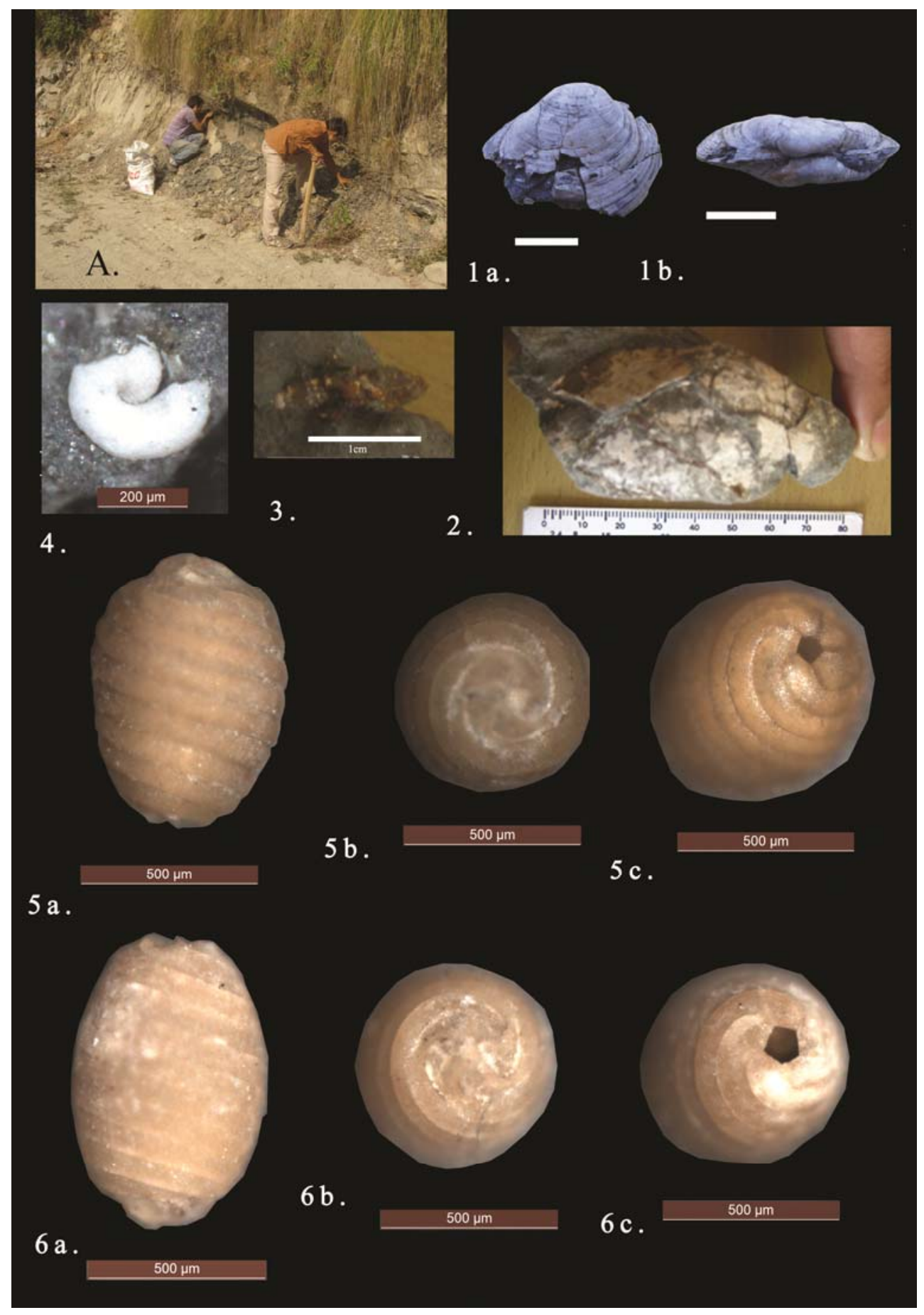

Plate-1: fig. A: The mollusk, Charophytes, Ostracodes and fish teeth bearing mudstone bed near Kamakhya Temple, Polian Prohita ( Himachal Pradesh); fig. 1: Parreysia sp. (Si/pal/001), 1a is lateral view and $1 \mathrm{~b}$ is dorsal view; fig. 2: Lamellidens sp. (Si/pal/002) in lateral view; fig. 3: Melanoids sp. (Si/pal/003); fig. 4: Gyraurus sp. (Si/pal/004) in apical view; fig. 5: Chara globularis globularis (Si/pal/005); fig. 6: Chara globularis aspera (Si/pal/006); Figs, 5a, 6a are lateral view, 5b, 6b are apical view and 5c, 6c are basal view. 
Open access e-Journal

Earth Science India, eISSN: $0974-8350$

Vol. 8 (I), January, 2015, pp. 15-31

http://www.earthscienceindia.info/

\section{Genus: Lychnothamnus_(Ruprecht) A.Braun, 1856 \\ Lychnothamnus breviovatus Lu \& Luo}

(Plate 2: fig. 2)

Materials and Horizon: -- $\mathrm{Si} / \mathrm{pal} / 008$ and several specimen of collected from dark grey to blackish mudstone bed of Dhok Pathan Formation near Kamikhya Temple, Polian Prohita area.

Comments: - The gyrogonite is small to medium in size, broadly ovoidal to nearly spheroidal, apical broadly rounded to sub-truncate, eight to twelve, convex, moderately thick convolution without distinct groove in the apical periphery, apical cell are jointed along a short zig-zag line, basal pore pentagonal to sub-circular, basal plug thinner than wide.

Remarks: - Bhatia (1999) described Lychnothamus breviovatus from the DhokPathan Formation near Daulatpur area and Pinjore Formation near Choti Parch village. Bhatia et al. (1985) has also reported Lychnothamus breviovatus from the Karewas of Kashmir. Originally the specimen had been described from the Late Oligocene and Neogene of Tarim Basin, XinJiang, China (Bhatia, 1999).

Genus: Lamprothamnium Groves, 1916

Lamprothamnium papulosum (Wallr.) Groves, 1924

(Plate 2: fig. 3)

Materials and Horizon: -- Si/pal/009 and several specimens from dark grey to blackish mudstone bed of Dhok Pathan Formation near Kamikhya Temple, Polian Prohita area.

Comments: - The Gyrogonites are small to medium size, prolate spheroidal to subprolate; the characteristic thin apical portion not preserved; ten to twelve, flat to concave, moderately thick convolution without any ornamentation. In lateral view, the spiral cells truncate towards the top. Basal pore moderately wide, pentagonal shape; basal plug thinner than wide.

Remarks: - The Genus Lamprothamnium was first time record from the Indian soil by Bhatia (1999). His collection comprises Lamprothamnium papulosum, Lamprothamnium succinctum from the Pinjor Formation of Upper Siwalik from Nada village in which he suggested an oligoto mesohaline environment. The Genus Lamprothamnium is euryhaline and thrives best in brackish water condition (Souli-Marsche, 1991). The present finding extends the geological range of the species up to Dhok Pathan Formation.

\section{Family: Candonidae Kaufmann, 1900 \\ Subfamily: Candoninae Kaufmann, 1900 \\ Genus: Candona Baird, 1845 \\ Candona sp.}

(Plate 2: figs. 4, 5)

Materials and Horizon: -- Two specimens (S Si/pal/010 and Si/pal/011) from dark grey to blackish mudstone bed of Dhok Pathan Formatio near Kamikhya Temple, Polian Prohita area.

Comments:- Carapace elongate subreniform, compressed in lateral view, with greatest height posterior to middle; left valve slightly larger than right valve; dorsal margin gently convex, slopping anteriorly and posteriorly from greatest height; ventral margin curved anteromedially; 
anterior margin narrow, obliquely rounded; posteriormargin broad and obliquely rounded; posterodorsal straight, posteroventral rounded; anterior and posterior ends nearly at same height; in dorsal view carapace lanceolate; ends compressed, maximum width near posterior to middle.

Remarks: - The present species resembles in overall lateral outline with Candona cachensis Swain (1947) described from Plio-Pleistocene, Salt Lake Formation, Utah. Unlike the present species $C$. cachensis has maximum height posteriorly, is more rounded posterodorsally, and posteroventrallyand in dorsal view ends rounded.

\section{Subfamily: Stenocyprinae \\ Genus: Stenocypris Sars, 1889 \\ Stenocypris sp. indet 1.}

(Plate 2: fig. 6)

Materials and Horizon: -- Single specimen (Si/pal/012) from dark grey to blackish mudstone bed of Dhok Pathan Formation near Kamikhya Temple, Polian Prohita area.

Comments:- Carapace broken, small, elongate in lateral view, with greatest height anteriorly; dorsal margin not well preserved and the ventral straight to slightly curved in the middle, the anterior and the posterior margins are rounded; left valve larger than right valve, overlap all along margins. The external surface of the carapace is smooth.

Remarks: -The present specimen resembles Stenocypris major of Bhandhari and Kundal (2008). However, the incomplete nature of preservation makes it difficult to assign it in a particular species.

\section{Stenocypris sp. indet. 2}

(Plate 2: figs. 7, 8)

Materials and Horizon: - Two specimens (Si/pal/013 and Si/pal/014) of collected from dark grey to blackish mudstone bed of Dhok Pathan Formation near Kamikhya Temple, Polian Prohita area.

Comments: - The specimens are well preserved, small, elongated in outline with length greater than three times its height; dorsal and the ventral margins are straight and the posterior and the anterior margins are rounded. The surface is smooth. The present specimens resemble Stenocypris fontinalis which is a long ranging specimen (Dhok Pathan, Tatrot and Pinjore formation). The Genus Stenocypris are usually found in warm and shallow water conditions (Stenocypris major; Baird, 1859; Bhatia \& Khosla, 1967to clean running water. Moroni (1967) observed that the Genus is also found in the paddy field.

Class: Actinopterygii Klein, 1885

Order: Perciformes, Bleeker, 1859

Family: Channidae, Fowler, 1934

Gen. et. sp. indet

(Plate 3; figs. 1, 2, 3)

Material and Horizon: Premaxillary teeth $\mathrm{Si} / \mathrm{pal} / 01$ to $\mathrm{Si} / \mathrm{pal} / 03$ from dark grey to blackish mudstone bed of Dhok Pathan Formation near Kamikhya Temple, Polian Prohita area.

Remarks: The teeth are small, conical in shape, well preserved, complete, apically inclined and constricted sub-basally; the cylindrical crown is tapering upward, enamel at the base present 
Open access e-Journal

Earth Science India, eISSN: $0974-8350$

Vol. 8 (I), January, 2015, pp. 15-31

http://www.earthscienceindia.info/

vertical stripe or wrinkle. The crown of the teeth posses thin layer of enameloid and the proximal part of the teeth bear striation on the surface. Similar teeth were collected from the lower and Upper Karewa of Kashmir by Kotlia $(1985,1989)$ in which he classified the teeth under the subfamily Schizothorax esocinus. The present teeth are also similar with those of Parmar and Prasad (2012) in having conical shape, presence of striation at the proximal part. However, their specimens posses more pointed apex at the crown. Similar teeth have also been recorded by Kotlia and Mathur (1997) from the upper Siwalik deposit of Surai Khola, Nepal.

\section{Division: Teleostei, Muller, 1846 \\ Superorder: Ostariophysi Sagemehl, 1885 \\ Order: Cypriniformes Bleeker, 1859/60 \\ Family: Cyprinidae Cuvier, 1817 \\ Gen. et. Sp. Indet}

Material and Horizon: Si/pal/015 to Si/pal/028 from dark grey to blackish mudstone bed of Dhok Pathan Formation near Kamikhya Temple, Polian Prohita area.

\section{Morphotype A}

(Plate 3; figs. 4, 5, 6)

Remarks: The teeth are small, short and complete; the base is swollen and subglobular in outline. The crown is unicuspate, acute and terminates distally in a short, conical hook; the masticatory area below the hook is slightly developed. Similar teeth have been reported from the Karewas of Kashmir, from the Upper Siwalik subgroup of Jammu and Kashmir near Khanpur village by Kundal and Prasad (2011) and Lower Siwalik beds of Jammu (Parmar and Prasad, 2012). These teeth are also comparable with the Cyprinidae teeth from the Lower-Middle Eocene of Kuldana Formation of Pakistan (Gayet, 1987, fig. 17) in having globular shape, oval cross section, slightly blunt and bend hook, narrow and moderately developed grinding surface. Gayet (1987) suggested such teeth may belong to outer row of fifth phyringeal.

\section{Morphotype B}

(Plate 3; Figs. 7, 8, 9, 10)

The teeth are elongate, cylindrical and globular in shape. In cross section, the teeth bear oval shape. The cylindrical bodies are slightly constricted at the base; the crown is acute.

\section{Morphotype C}

(Plate 3; figs. 11, 12, 13, 14)

The teeth are elongated, complete, occlusal plane is strongly oblique and bear laterally flattened crowns. The teeth are inflated towards the apical portion and tapering down at the base. Crowns are bounded by elongated crests enclosing a central shallow depression. These members were reported by Kotlia (1985) from the Karewas of Kashmir, from the Upper Siwalik subgroup of Jammu and Kashmir near Khanpur village by Kundal and Prasad (2011). 


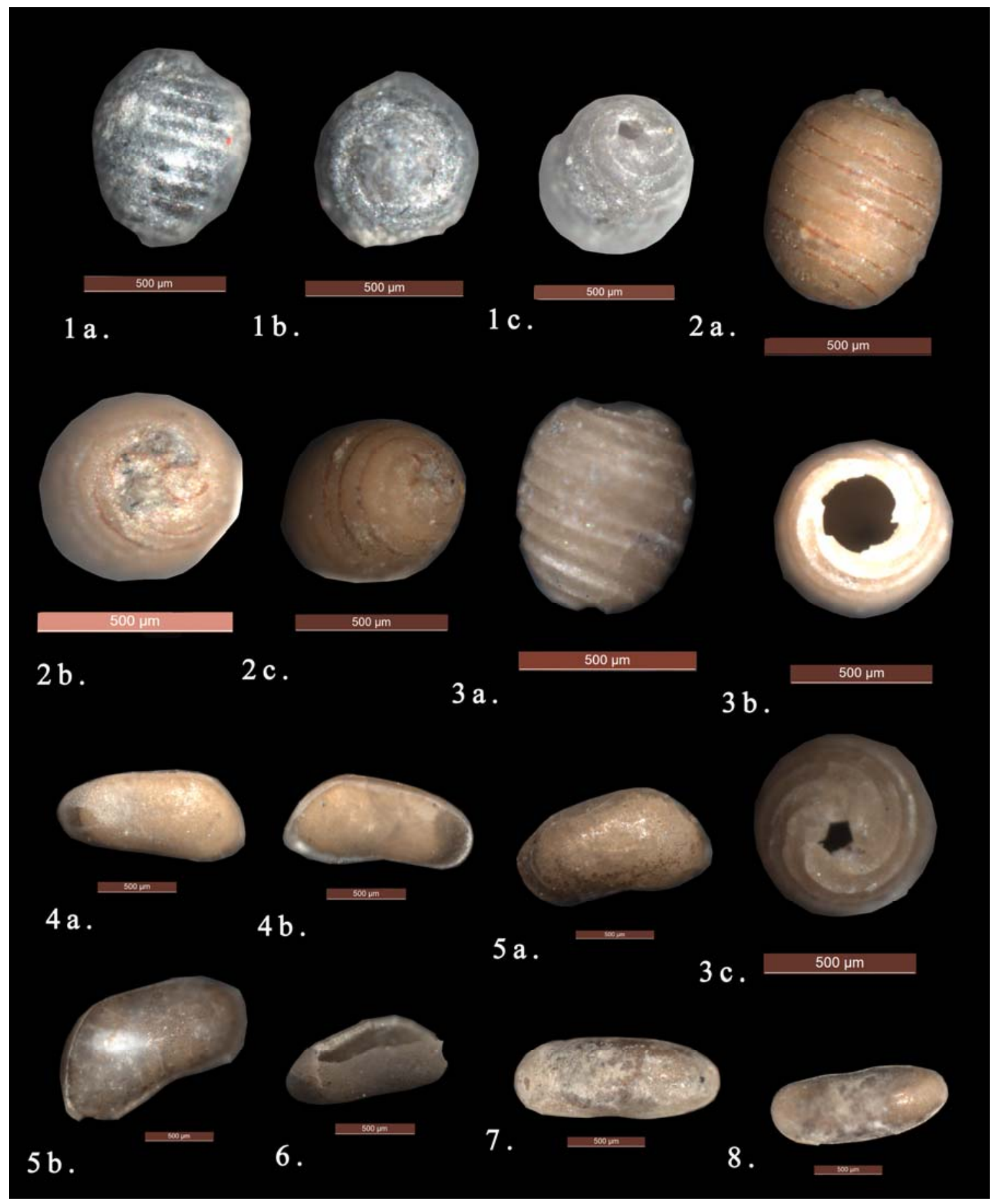

Plate-2: fig. 1: Chara sp. indet. (Si/pal/007); fig. 2: Lychnothamus breviovatus (Si/pal/008); fig. 3: Lamprothamnium papulosum (Si/pal/009); fig. 4, 5: Candona sp. (Si/pal/010; Si/pal/011); figs. 6: Stenocypris sp. indet 1. (Si/pal/012) in lateral view; figs. 7, 8: Stenocypris sp. indet. 2 (Si/pal/013, Si/pal/014) in lateral view; Figs. 1a, 2a and 3a are in lateral view, figs. 1b, 2b and 3b are in apical view and figs. 1c, 2c and 3c are in basal view. Scale bar represent 500 $\mu \mathrm{m}$. 
Open access e-Journal

Earth Science India, eISSN: $0974-8350$

Vol. 8 (I), January, 2015, pp. 15-31

http://www.earthscienceindia.info/

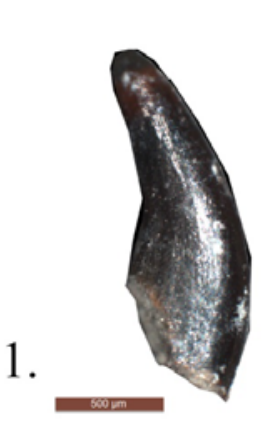

2.

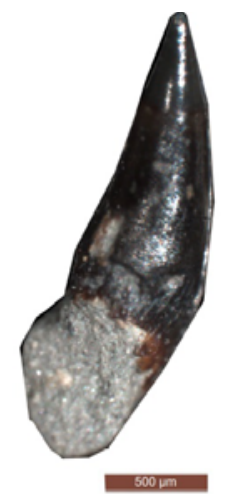

3.

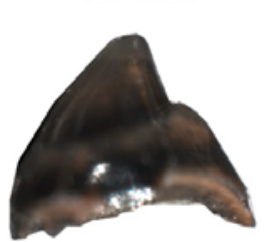

6.

5.
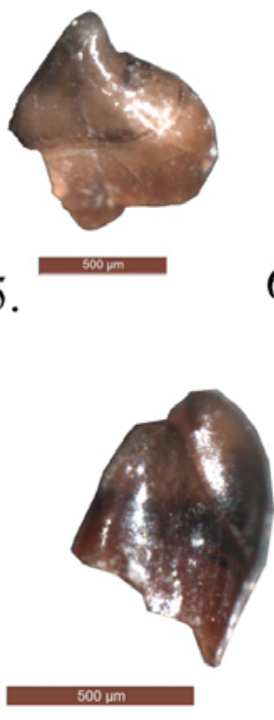

9.

10.

13.
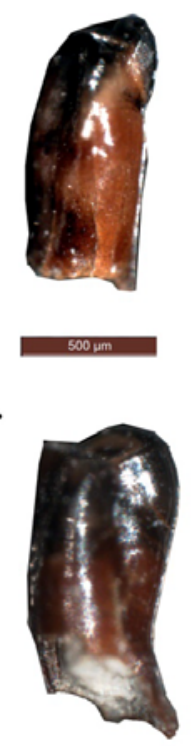
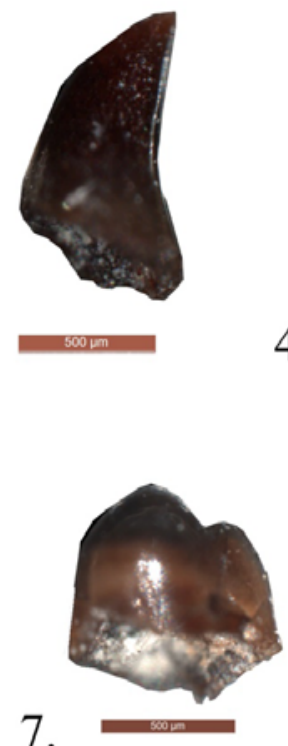

8.

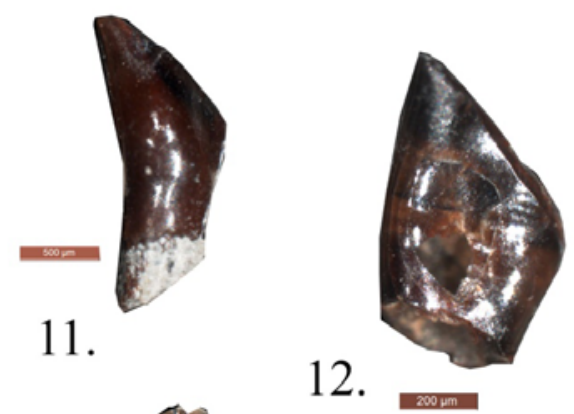

4.
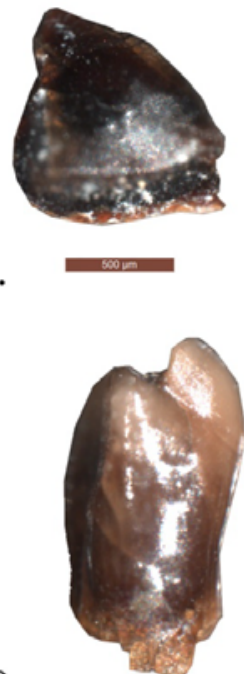

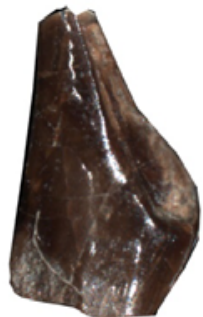

14.

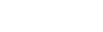

Plate-3: Figs. 1, 2 and 3: Channidae teeth (Si/pal/015, Si/pal/016, Si/pal/017); Fig. 4, 5 and 6: Cyprinidae teeth (Si/pal/018, Si/pal/019 and Si/pal/020), Morphotype A; Figs. 7, 8, 9 and 10: Cyprinidae teeth (Si/pal/021, Si/pal/022, Si/pal/023 and Si/pal/024), Morphotype, B; Figs. 11, 12, 13 and 14: Cyprinidae teeth(Si/pal/025, Si/pal/026, Si/pal/027 and Si/pal/028), Morphotype C. All the figures are in lateral view. Scale bar in figs. $1-13$ is 500 um and fig. 14 is $1 \mathrm{~mm}$. 


\section{Discussion and Conclusion}

On the basis of the above microfossil assemblages including the gyrogonites of charophytes which are associated with ostracods, mollusc and fossil fish teeth a broad palaeoenvironmental condition of the area can be reconstructed. Interestingly, most of these fossils are restricted to a particular mudstone band which is dark grey and carbonaceous in nature attaining a maximum thickness of about one metre. The charophyte flora of the study area comprises Chara globularis globularis, Chara globularis aspera, Chara sp. indet, Lychnothamus breviovatus, Lamprothamnium papulosum, etc. In ideal case, the genus Chara is typical of shallow plain lakes while those of the intermontane and foothills depressions were inhabited by Lychnothamus. The abundance of well preserved charophyte gyrogonites suggests a semi-permanent to permanent pond or lacustrine environment. The recovery of the fresh water cyprinid fishes associated with charophytes, ostracods and freshwater mollusks restricts the depositional environment of this unit to very low energy condition. An enhanced seasonal flooding is essential to produce a local lacustrine condition on the overbanks. Ostracods inhabit every aquatic environment, which includes fresh, brackish and marine waters. They are very sensitive to change in the environment. The most commonly abundant forms of ostracods species found in this dark grey carbonaceous mudstone bed includes Stenocypris sp., Candona sp. These species are commonly found well adapting in the warm, shallow water ponds and lakes (Bhatia and Singh, 1977; Bhatia,1996). Amongst the mollusks, Parreysia sp., Lamilliden sp., Melanoides tuberculata, Gyraulus sp. etc. indicates a warm tropical to subtropical humid climatic condition. The Lithounits of the Dhok Pathan Formattion are dominated by Sm, Sh, St and Fsm of Miall (1989) Lithofacies code deposited by large meandering to braided river system undergoing frequent avulsion (Singh et al., 2012). The sedimentary facies of dominant unchannelized sandstone bodies along with low mudstone unit of Dhok Pathan Formation suggests their deposition during sheet floods in a braided stream environment. Taking into consideration of the fossil assemblages from this carbonaceous dark grey to blackish colour mudstone bed, it may suggested that there used to exist a localized swampy to overbank pond environment at this deposit of braided river system of Dhok Pathan Formation.

Acknowledgements: The author is highly thankful to Director General, Geological Survey of India for kind permission to publish this piece of work. Guidance from Shri Inder Singh (Rtd. Director, GSI, Chandigarh) during the field work for the Field Season 2011-12 under the FSP No. STM/NR/PHH/2010/005 is highly thankful. Helps from Prof. Rajeev Patnaik (Panjab University) and Dr. S. Shome (Director, GSI, CHQ, Kolkata) during the preparation of manuscript is highly acknowledged. The authors are equally thankful to Prof. Ashok Sahni (Lucknow University) and Dr. O.N. Bhargava (Retd. Director, GSI) for the valuable suggestions and encouragement. The authors are grateful to Dr. V.P. Mishra (Rtd. DDG, GSI) for valuable suggestions and meticulously review of the manuscript.

\section{Reference}

Baird, W. (1859) Description of some new Entomostraca from Nagpur, collected by S. Hislop. Proceeding of the Zoological Society of London, v. 389, pp. 231-234.

Benthem Jutting, Van, W.S.S. (1950) Systematic studies on the non- marine mullusca of the Indo-Australian Archepelego. V. Critical Revision of the Javanese Freshwater Gastropods, Treubia, v. 23(2), pp. 259-477.

Bhandari, A. and Kundal, S.N. (2008) Ostracodes from the Nagrota Formation, Upper Siwalik Subgroup, Jammu, India. Revista Espanola de Micropalaeontologia, v. 40(1-2), pp. 151-166.

Bhatia, S. B. (1996) The ostracode fauna and the charophyte flora of the Siwalik Group: Palaeogeographic and Palaeoecologic implications. Publication Centre of Advanced Study in Geology, Panjab University, Chandigarh, v. 5, pp. 99-106. 
Bhatia, S. B. and Khosla, S.C. (1967) A preliminary note on the discovery of Ostracodes from the Upper Siwalik, near Chandigarh. Bulletin of the Geological Society of India, v. 58, pp. 509-518.

Bhatia, S. B. and Mathur, A. K. (1973) Some Upper Siwalik and Late Pleistocene mollusks from Punjab. Himalayan Geology, v. 3, pp. 24-58.

Bhatia, S. B. and Mathur, A. K. (1978) The Neogene charophyte flora of the Siwalik Group, India and its biostratigraphical significance. Geophytology, v. 8(1), pp.79-97.

Bhatia, S. B. and Singh, D. (1977) Some Late Pleistocene and Recent Ostracoda from parts of Punjab and the Union Territory of Chandigarh, India. Recent Researches in Geology, v. 3, pp. 399-414.

Bhatia, S. B. and Singh, N. (1989) Holocene charophytic flora of Uttar Pradesh, India: biogeographic implications. First International Symposium Charophytes, Montpellier, Abst. pp. 5.

Bhatia, S. B. (1996) The ostracod fauna and the charophyte flora of the Siwalik Group: Palaeogeographic and Palaeoecologic implications. Publication Centre of Advanced Study in Geology, Panjab University, Chandigarh, v. 5, pp. 99-106.

Bhatia, S.B. (1982) Facies, fauna and flora of the Lower Tertiary Formations of Northwestern Himalayas: A synthesis. Journal of Palaeontological Society of India, v. 1, pp. 8-20.

Bhatia, S.B. (1999) Revision of the Charophyte flora of the Siwalik Group (Neogene- Quaternary) of the Lesser Himalaya, India. (Aust. J. Bot.) Australian Journal of Botany, v. 47, pp. 459-474.

Bhatia, S.B. and Mathur, A. K. (1971) Late Pleistocene gastropods from Nalagarh Tehsil, Himachal Pradesh. Journal Geological Society India, v. 12(3), pp. 280-285.

Bhatia, S.B. and Mathur, A. K. (1978) The Neogene Charophytes flora of the Siwalik Group, India, and its biostratigraphical significance. Geophytology, v. 8, pp.78-97.

Bhatia, S.B., Batra, R.S. and Kotlia, B.S. (1985) A note on the charophytic flora of the Lower Karewa sediments of the Romushi and Hirpur section, Kashmir, India. In: D.P. Agarwal, S. Kusumgarh and R.V. Krishnamurthi (eds.) Climate and Geology of Kashmir and Central Asia, pp. 53-56. (Today’s and Tomorrow's printers and Publishers: New Delhi).

Brown, D.S. 1965. Freshwater Gastropod Mollusca from Ethiopia. Bull. Brit. Mus. (Nat. Hist.) Zool., Bulletin of the British Museum (Natural History), Zoology. v. 12(2), pp. 37-94.

Burbank, D. N., Beck, R. A. and Mulder, T. (1996) The Himalayan foreland basins. In: A. Yin and T. M. Harrison (eds.), Tectonic Evolution of Asia, Cambridge University Press, pp. 149-188.

Gayet, M. (1987) Lower vertebrates from the Early-Middle Eocene Kuldana Formation of Kohat (Pakistan): Holeistei and Teleostei. Contributions Museum of Palaeontology, University of Michigan, v. 27, pp.151-168.

Gurung, D. (1998) Freshwater molluscus from the Late Neogene Siwalik Group Khola, Western Nepal. Journal Nepal Geological Society, 17: 7-28.

Johnson, G.D. (1977) Paleopedology of Ramapithecus-bearing sediments, North India. Geol. Rundsch., v. 66, pp.192-216.

Johnson, G.D., Opdyke, N.D., Tandon, S.K. and Nanda, A.C. (1983) The magnetic polarity stratigraphy of the Siwalik Group at Haritalyangar (India) and a new last appearance datum for Ramapithecus and Sivapithecus. Palaeogeography, Palaeoclimatology, Palaeoecology, v.72, pp. 223-249.

Johnson, N. M., Opdyke, N. D., Johnson, G. D., Lindsay, E. H. and Tahirkheli, R. A. K. (1982) Magnetic polarity stratigraphy and ages of Siwalik Group rocks of the Potwar Plateau, Pakistan: Palaeogeography, Palaeoclimatology, Palaeoecology, v. 37, pp. 17-42.

Johnson, N. M., Stix, J., Tauxe, L., Cerveny, P. F. and Tahirkheli, R. A. K. (1985) Paleomagnetic chronology, fluvial processes, and tectonic implications of the Siwalik deposits near Chinji Village, Pakistan. Journal of Geology, v. 93, pp.27-40.

Kotlia, B.S. (1985) Vertbrate palaeontology and palaeoecology of the Karewa Group, Kashmir: A biostratigraphic study. Unpublished Ph.D. Thesis Panjab University, Chandigarh, 1-310.

Kotlia, B.S. (1989) Pliocene-Pleistocene fossil fish remains from Kashmir valley, NW India: Biochronology, systematic and palaeoecology. Jour. Geological Society of India, v. 34, pp.19-39.

Kotlia, B.S. and Mathur, D.P. (1997) Lower vertebrate fauna from the Upper Siwaliks of Surai Khala, Dang Valley western Nepal. Jour. Palaeontological Society of India, v. 42, pp.169-173.

Kumar, R. and Nanda, A.C. (1989) Sedimentology of the Middle Siwalik subGroup of Mohand area, Dehra Dun valley, India. Jour. Geological Society of India, v. 34, pp.597-616.

Kumar, R., Ghosh, S.K. and Sangode, S.J. (2004) Depositional environment of Mio-Pliestocene coarse clastic facies 
in the Himalayan Foreland Basin, India. Himalayan Geology, v. 25, pp.101-120.

Kumaravel, V., Sangode, S.J., Siva Siddaiah, N. and Kumar, R. (2005) Rock magnetic characterization of pedogenesis under high energy depositional conditions: a case study from the Mio-Pliocene Siwalik fluvial sequence near Dehra Dun, NW Himalaya, India. Sedimentary Geology, v. 177, pp. 229-252.

Kumaravel, V., Sangode, S.J., Siva Siddaiah, N. and Kumar, R. (2009) Major element geochemical variations in a Miocene-Pliocene Siwalik paleosol sequence: implication to soil forming processes in the Himalayan Foreland Basin. Jour. Geological Society of India, v. 73, pp.759-772.

Kumaravel, V., Sangode, S.J., Siva Siddaiah, N. and Kumar, R. (2010) Interrelationship of magnetic susceptibility of soil colour and elemental mobility of the Pliocene-Pliestocene Siwalik palaeosol sequences of the NW Himalayas, India. Geoderma, v. 154, pp. 267-280.

Kundal, S. N. and Prasad, G.V.R. 2011. ? Late Pliocene- Early Pleistocene Microvertebrates from the Upper Siwalik Subgroup of Jammu, Jammu and Kashmir, India. Earth Science India, 4(III): 143-158.

Kundal, S. N., Prasad, G. V. R. and Bhat, G. M. (2008) Charophytes from the Nagrota Formation, Upper Siwalik Subgroup of Jammu, Jammu and Kashmir, India. Plant Life through ages, Abstract, pp.81.

Lakhanpal, R. N., Kapoor, S. and Jain, K. P. (1976) Some charophyte remains from the Lower Siwalik of Tanakpur, District Nainital. Palaeobotanist, v. 23, pp. 40-43.

Lakhanpal, R.N. and Guleria, G.S. (1987) Fossil leaves of Dipterocarpus from the Lower Siwalik beds near Jawalamukhi, Himachal Pradesh. Palaeobotanist, v. 35(3), pp. 258-262.

Liu, Jum-Ying (1989) Discovery of fossil charophytes from the lower member of the Binai Khola Formation, the Chuaria (Siwalik) Group in Nepal. Acta Micropalaeontologia Sinica, v. 6, pp. 311-318.

Mathur, A. K. (1975) Biostratigraphy and Palaeontology of the Siwalik Group and Late Pleistocene deposits of parts of Himachal Pradesh, Panjab and Haryana. Unpublished Ph.D. Thesis, Panjab University, Chandigarh, 361p.

Mathur, A.K. (1998) Additional molluscan fauna and taxonomic review of molluscs from the Siwalik Group and Terrace deposits, Himachal Pradesh, Panjab and Haryana. Geoscience Journal, v.19(1), pp.33-75.

Meigs, A.J., Douglas W. and Beck, R. A. (1995) Middle-late Miocene (10 Ma) formation of the Main Boundary thrust in the western Himalaya. Geology, v. 23(5), pp. 423-426.

Miall, A.D. (1989) Architectural elements and bounding surfaces in channelized clastic deposits: Notes on comparison between fluvial and turbidite systems. In: A. Taira and F. Masuda (eds.), Sedimentary facies in the active plate margin. Terra scientific publishing company (Terrapub), Tokyo, pp. 3-15.

Moroni, A. (1967) Ostracodi dellerisaie italiane. Societa Cooperative. Editrice Libraria. a. r. 1, Parma, pp. 1-79.

Nanda, A.C. (1997) Some biostratigraphic observations based on the Upper Siwalik Faunas of the Siwalik Group of India and Nepal. In: N.P. Wijayananda, P.G. Cooray, and P. Mosley (eds.), Geology in South Asia - II. Geological Survey and Mines Bureau, Dehiwala, Sri Lanka, pp. 171-189.

Parmar, V. and Prasad, G.V.R. (2012) Fossil fish fauna from the Lower Siwalik beds of Jammu. Jour. Geological Society of India, v.57(1), pp.43-52.

Patnaik, R. (2003) Reconstruction of Upper Siwalik Palaeocology and Palaeoclimatology using Microfossil Palaeocommunities. Palaeoecology, Palaeoclimatology and Palaeogeography (special volume), v. 197(1-2), pp. 133-150.

Pilgrim G.E. (1934) Correlation of fossiliferous section in upper Cenozoic of India. American Museum Novitates, v. 704, pp. 1-5.

Pilgrim, G.E. (1910) Preliminary note on a revised classification of the Tertiary freshwater deposits of India. Records of the Geological Survey of India, v. 40, pp. 185-188.

Pilgrim, G.E. (1913) The correlation of the Siwaliks with the mammalian horizons of Europe. Records Geological Survey of India, v. 43, pp. 264-325.

Prasad, B. (1927) On some fossil Indian Unionidae. Records Geological Survey of India, v. 56(3), pp. 210-212.

Proctor, V.W. (1980) Historical biogeography of Chara (Charophyta): an appraisal of the Braun-Wood classification plus a falsifiable alternative for future consideration. Jour. Phycology, v. 16, pp.218-233.

Raghavan, P. (1990) New records of microfossils assemblages from the basal Pinjor Formation at Panchkula. Bulletin of Indian Geological Association, v. 23, pp. 29-38.

Ranga Rao, A., Agarwal, R.P., Sharma, U.N., Bhalla, M.S. and Nanda, A.C. (1988) Magnetic polarity stratigraphy and vertebrate paleontology of the upper Siwalik subgroup of Jammu Hills, India. Jour. Geological Society of India, v. 31, pp. 361-385.

Retallack, G.J. (1995) Paleosols of Siwalik group as a 15 Ma record of south Asian palaeoclimate. Memoir Geological Society of India, v. 32, pp. 36-51.

Sangode, S.J., Bloemenda, J., Kumar, R. and Ghosh, S.K. (2001) Plio-Pleistocene pedogenic changes in the Siwalik palaeosols: A rock magnetic approach. Current science, v. 81(4), pp. 387-392. 
Open access e-Journal

Earth Science India, eISSN: $0974-8350$

Vol. 8 (I), January, 2015, pp. 15-31

http://www.earthscienceindia.info/

Sangode, S.J., Kumar, R. and Ghosh, S.K. 2003. Magnetic polarity stratigraphy of the Late Miocene Siwalik Group sediments from Kangra Re-entrant, H.P., India. Himalayan Geology, v. 24, pp. 47-61.

Sanyal, P., Bhattacharya, S.K., Kumar, R., Ghosh, S.K. and Sangode, S.J. (2004) Mio-Pliocene monsoonal record from Himalayan foreland basin (Indian Siwalik) and its relation to vegetational change. Palaeogeography, Palaeoclimatology, Palaeoecology, v. 205, pp. 23-41.

Singh, S. S., Sukla, A., Bhagawati, Ch., Milankumar, K. Sh., Vipina, P.V. and Kumbkarni, S. (2012) Report on Delineation of lithostratigraphic units of Siwalik Belt in Kangra, Hamirpur, Mandi, Bilaspur and Una districts, Himachal Pradesh and Ropar district, Punjab. Geological Survey of India, Unpublished field report for the Field season: 2010-12; 116p.

Soulie-Marsche, I. (1991) Charophytes as lacustrine biomarkers during the Quaternary in North- Africa. Journal of African Earth Sciences, v. 12, pp. 341-351.

Swain, F .M. (1947) Tertiary non-marine Ostracoda from the Salt Lake Formation, Northern Utah. Jour. Paleontology, v. 21, pp. 518-28.

Tandon, S. K. (1991) The Himalayan Foreland: Focus on Siwalik Basin. In: S. K., Tandon, C. C. Pant and Casshyap, S. M. (eds.) Sedimentary Basins of India: Tectonic Context, Gyanodaya Prakashan, Nainital, pp. 177-201.

Tewari, B.S. and Sharma, S.P. 1972. Some fossil charophyta from Upper Siwalik near Chandigarh, India. Bulletin Indian Geologists' Association, v. 5, pp. 1-22.

Thomas, J.V., Parkash, B. and Mohindra, R. (2002) Lithofacies and palaesolanalysis of the Middle and Upper Siwalik Groups (PlioPleistocene), Haripur-Kolar section, Himachal Pradesh, India. Sedimentary Geology, v. 150, pp. 343-366.

Vokes, H. E. (1935) Unionidae of the Siwalik Series. Memoirs of the Connecticut Academy, v. 9(4), pp. 37-48.

(Received: 28.10.2014; Accepted: 18.1.2015) 